\title{
GROWTH OF OYSTERS (OSTREA EDULIS L.)
}

\author{
By P. R. WALNE \\ Fisheries Experiment Station, Conway
}

(Text-figs. I-I I)

\begin{abstract}
Although the biology of the oyster Ostrea edulis has been well studied, its growth has received little attention. Orton (1928) worked on the populations in the Rivers Fal and Blackwater, but his conclusions have not been supported by Havinga (1928) or Korringa (1955), while America studies on Crassostrea virginica have given further evidence of the need for new investigations.

As the Conway breeding experiments necessitate the maintenance of a small oysterage at Tal-y-foel, Anglesey, stocked with oysters of known age and homogeneous origin, a good opportunity was available for studying the growth of marked or isolated oysters. This paper records some observations on the seasonal and annual patterns and on the effect of tidal exposure.
\end{abstract}

\section{CONDITIONS AND EXPERIMENTAL METHODS}

The position of the oysterage is shown in Fig. I. The beach above mid-tide level is of steeply sloping shingle; but below this level the slope is much more gradual and the beach varies from mud with varying proportions of sand to small shingle bound together by mud and sand. Near Tal-y-foel pier there is a small, exploited, mussel bed; while the oyster grounds are occasionally picked over for periwinkles. The lower part of the shore, where the oysters are kept, is protected from rough weather by a sand bank, Traeth Gwyllt, separating the Tal-y-foel inlet from the main channel. A tidal current of $\mathrm{I}-2$ knots flows parallel with the shore, associated with a tidal range of about $17 \mathrm{ft}$. at springs and $10 \mathrm{ft}$. at neaps.

Salinity samples were taken only at low water springs-the time of lowest salinity - as, when the tide is up, the local drainage water from small streams has less influence. Most of the samples (Fig. 2) were of a salinity of $31 \%$ or more; lower records were scattered roughly at random throughout the year, and were probably associated with recent heavy rain which, as consecutive samples show, has no lasting effect.

Water temperature was recorded by a thermograph for 17 months. From these records it was found that the mean monthly water temperature could be estimated from the mean monthly air temperature at Valley, I3 miles to the north-west, as published in the Monthly Weather Report of the Meteorological Office (Fig. 3). The regression calculated from this data allows the 
mean water temperature at the oysterage to be estimated with an error of less than $0.5^{\circ} \mathrm{C}$. For consistency, all the mean temperatures quoted in this paper are calculated from the Valley air temperatures using the curve shown in Fig. 3.

Observations on the position of low-water mark on a graduated staff showed that there was a close correlation between the level to which a given tide fell at Tal-y-foel and the level to which the same tide fell in Holyhead Docks (Fig. 4). As a tidal recorder was in continuous use at Holyhead, it was possible to calculate the number of times to which the tide fell to certain levels at Tal-y-foel in a given period. The amount of exposure to the air of

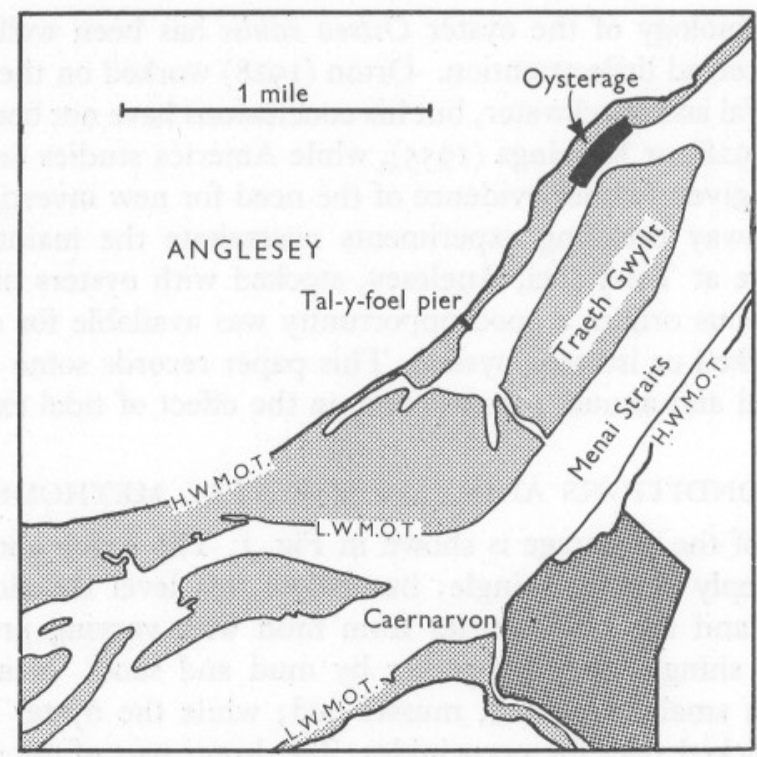

Fig. I. Map showing the position of the oysterage. The sand banks, exposed at low tide, are lightly stippled.

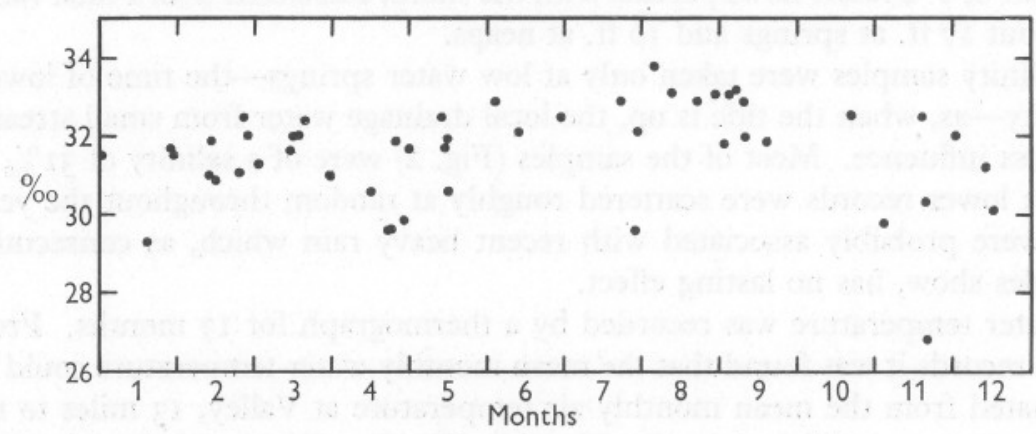

Fig. 2. Salinity of the water at low water of spring tides at the oysterage. The data covers the period December I95I-November 1953. 
various levels on the shore by tides of different heights was determined by setting up a continuously recording tide gauge for a period on the pier at Tal-y-foel, the instrument being calibrated in terms of levels at the oysterage. From these values, combined with the data on the frequency to which the tide fell to different levels, a tidal exposure curve for that part of the shore used for the oyster experiments has been calculated (Fig. 5).

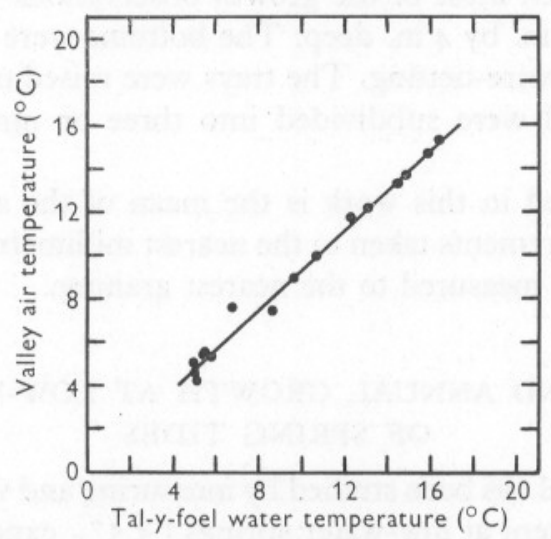

Fig. 3. The relation between the mean monthly air temperature at Valley, Anglesey, and the mean monthly water temperature at Tal-y-foel. The line drawn is the regression giving the best estimate of the water temperature from the air temperature.

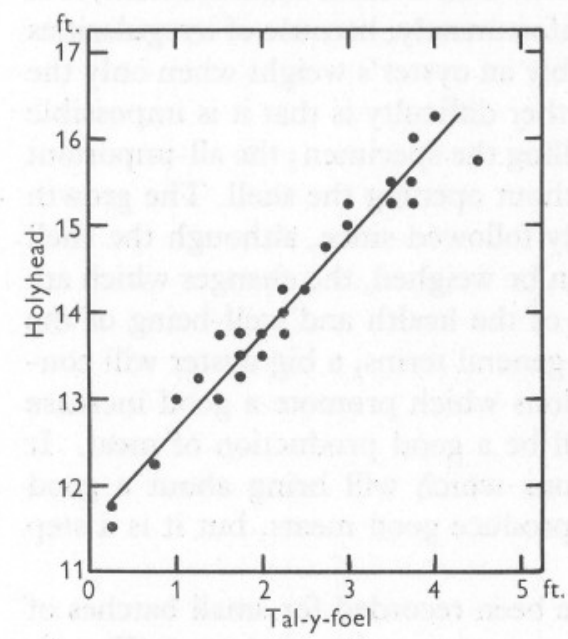

Fig. 4

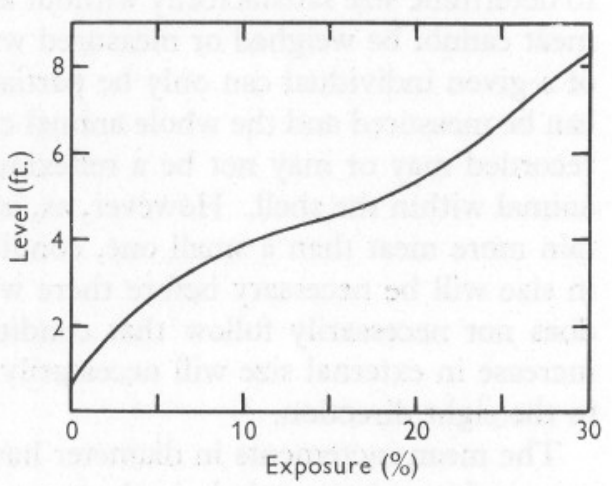

Fig. 5

Fig. 4. The relation between the height of low-water springs at Holyhead and Tal-y-foel. The line drawn is the regression giving the best estimate of the height of tide at Tal-y-foel.

Fig. 5. The percentage of the time for which the lower levels of the shore at Tal-y-foel are exposed. 
The general treatment of spat and older oysters in trays was that described and illustrated by Cole (1938). The oysters are first brought to the oysterage when I-2 months old, attached to earthenware tiles coated with a lime mortar. The tiles are wired together in bundles of ten and stood on racks at low-water mark. When the spat are about 12 months old they are stripped off the tiles and kept in wooden trays with wire tops and bottoms.

The trays in which most of the growth observations were made measure $5 \mathrm{ft}$. 4 in. by $3 \mathrm{ft}$. o in. by 4 in. deep. The bottoms were of $\frac{1}{2}$ in. woven wire and the top of $\frac{1}{2}$ in. wire-netting. The trays were raised on posts about 18 in. above the mud and were subdivided into three or nine compartments as required.

The diameter used in this work is the mean of the antero-posterior and dorsi-ventral measurements taken to the nearest millimetre below.The weight, when recorded, was measured to the nearest gramme.

\section{SEASONAL AND ANNUAL GROWTH AT LOW-WATER MARK OF SPRING TIDES}

Growth at Tal-y-foel has been studied by measuring and weighing at intervals, samples of oysters kept at low-water springs ( $<5 \%$ exposure). In some experiments the growth of marked individuals has been followed, and in others the mean increase in size or weight of groups has been recorded. While weight is a more useful parameter of growth than a linear measurement, it is not the easiest to measure in the field. Unfortunately, because of irregularities in shape, it is impossible to estimate reliably an oyster's weight when only the mean diameter has been recorded. A further difficulty is that it is impossible to determine size satisfactorily without killing the specimen; the all-important meat cannot be weighed or measured without opening the shell. The growth of a given individual can only be partially followed since, although the shell can be measured and the whole animal can be weighed, the changes which are recorded may or may not be a reflexion of the health and well-being of the animal within the shell. However, as, in general terms, a big oyster will contain more meat than a small one, conditions which promote a good increase in size will be necessary before there will be a good production of meat. It does not necessarily follow that conditions which will bring about a good increase in external size will necessarily produce good meats, but it is a step in the right direction.

The mean increments in diameter have been recorded for small batches of oysters for various periods in the years I945, I952, I953, and 1956 (Fig. 6). So as to give a satisfactory standard of comparison between periods of unequal length, the recorded increment for each period has been converted to the mean increment in 30 days. In general there was little or no growth between the beginning of November and the end of March, and, in fact, the diameter 
and weight usually decreased slightly in this period, due to the abrasion of the shell by winter storms. This happened both to oysters laid on the ground and to those in trays, as the following example, which gives the mean weight and mean length of two samples of 200 I 8 -month old oysters, shows:

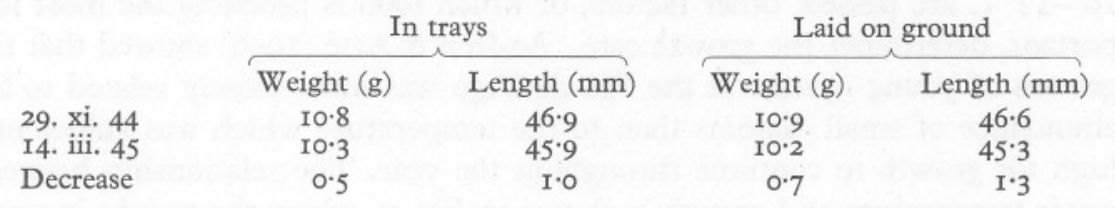
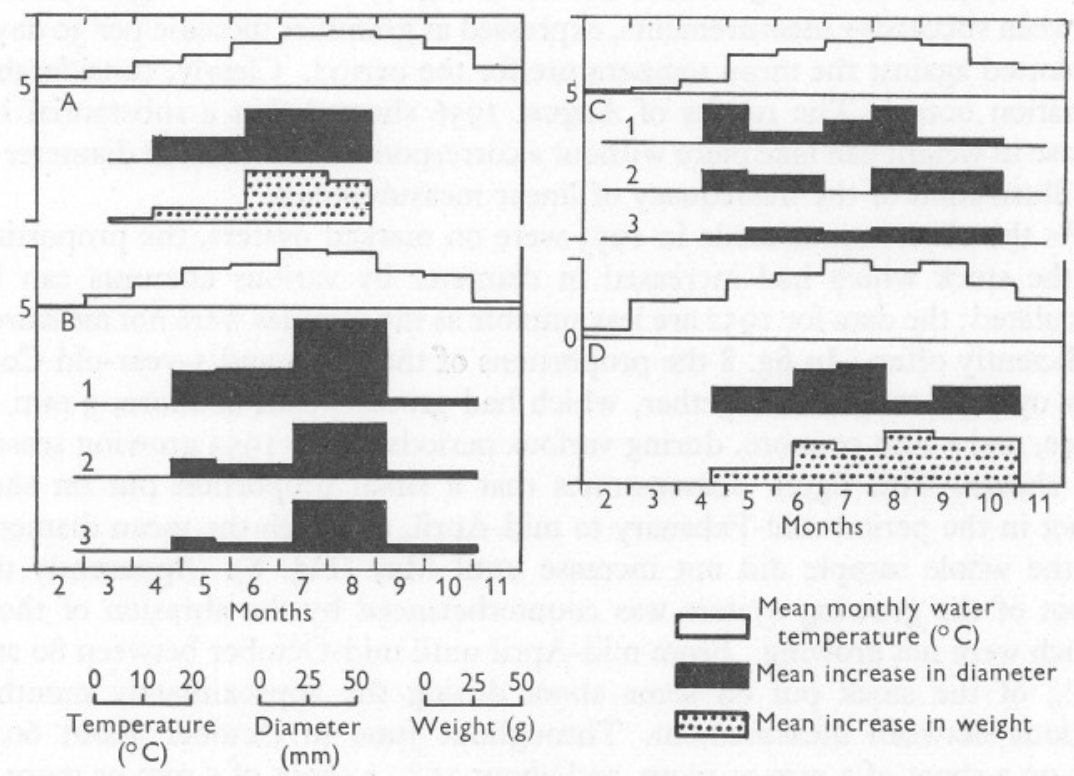

Fig. 6. Seasonal growth at Tal-y-foel. The increment, either mean diameter or mean weight, in the various periods has been calculated as the mean for 30 days. The base-line for all graphs is o except for three of the water temperatures where it is $5^{\circ}$. Vertical scales given at bottom left. A. 1945. Growth in mean diameter and weight of $1 \frac{1}{2}$-year-old oysters. B. 1952.

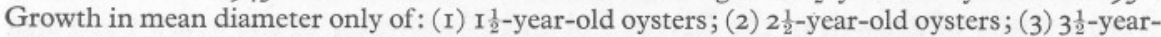
old oysters. C. 1953. Growth in mean diameter only of: (I) $2 \frac{1}{2}$-year-old oysters; (2) $3 \frac{1}{2}$-year-

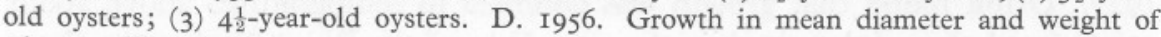
I $\frac{1}{2}$-year-old oysters.

In none of three years when observation began in the winter months was growth in mean diameter found in the April samples, although there was a slight increase in weight in 1954. In the samples taken in May growth was general-the mean temperature had risen to about $12^{\circ} \mathrm{C}$. Growth continued, the rate varying in different years, until October or early November. In September $195^{2}$ the temperature dropped rather sharply to $12.7^{\circ} \mathrm{C}$, and little subsequent growth occurred. In 1953 and 1956 when temperatures were 
higher, with means of $15.8^{\circ}$ and $16.0^{\circ} \mathrm{C}$ in September, and $12.0^{\circ}$ and II.9. $\mathrm{C}$ in October respectively, growth continued into October. These results suggest that the beginning and end of a season's growth, both in diameter and total weight, is controlled by temperature. Once the critical limits, about $10^{\circ}-12^{\circ} \mathrm{C}$ are passed, other factors, of which food is probably the most important, determines the growth rate. Andreu \& Arté (1956) showed that the growth of young oysters in the Ria de Vigo was more closely related to the abundance of small diatoms than to the temperature which was sufficiently high for growth to continue throughout the year. The relationship between water temperature and growth is shown in Fig. 7, where the weight increase between successive measurements, expressed as grammes increase per 30 days, is plotted against the mean temperature for the period. Clearly, considerable variation occurs. The results of August 1956 showed that a substantial increase in weight can take place without a corresponding increase in diameteran illustration of the inadequacy of linear measurements.

As the observations made in 1953 were on marked oysters, the proportion of the stock which had increased in diameter by various amounts can be calculated; the data for 1952 are less suitable as the samples were not measured sufficiently often. In fig. 8 the proportions of the 3-, 4- and 5-year-old Conway oysters, combined together, which had grown $\mathrm{I} \mathrm{mm}$ or more, $3 \mathrm{~mm}$ or more, and $5 \mathrm{~mm}$ or more, during various periods in the 1953 growing season are shown. This figure demonstrates that a small proportion put on shell shoot in the period mid-February to mid-April, although the mean diameter of the whole sample did not increase until May (Fig. 6). Apparently the shoot of the growing oysters was counterbalanced by the abrasion of those which were not growing. From mid-April until mid-October between 80 and $90 \%$ of the stock put on some shoot during the approximately monthly periods between measurement. Throughout June to October about $60 \%$ put on a shoot of $3 \mathrm{~mm}$ or more, and about $35 \%$ a shoot of $5 \mathrm{~mm}$ or more in each period of about a month. The variations from period to period are largely due to differences in the intervals between measurements.

These results differ in some respects from those obtained by Orton (I928) from a study of growth in the Rivers Fal and Blackwater in the years 1926 and 1927. Orton found that growth was confined to temperatures above about $10^{\circ} \mathrm{C}$, but believed that, both in the river Fal and the River Blackwater, there were two growing periods, one in the spring and one in the autumn, while in the summer months, June, July and August, there was no increase in diameter. In the Menai Straits, however, the proportion of oysters showing an increase in diameter (Fig. 7) rises during the spring and is maintained at an approximately constant level throughout the summer and drops again in the autumn; there was no period in the summer when growth in diameter did not occur.

Orton suggested that the cessation of growth in the summer was due to the 
energies of the Fal and Blackwater oysters being taken up by spawning activity, but, according to Korringa (1955), oysters are able to continue growing at a normal rate during the spawning period, provided that feeding conditions are satisfactory. An oyster which was weighed in water daily by Havinga (I928) spawned and brooded its larvae during the period of observation.

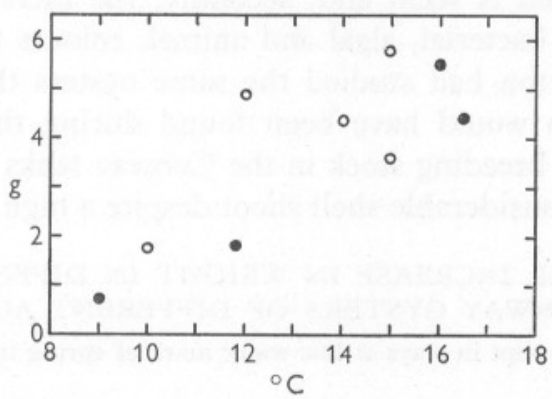

Fig. 7. The relation between mean water temperature and increment in weight in $\mathrm{I} \frac{1}{2}$-year-old Conway oysters for various periods in 1945 (solid circles) and 1956 (open circles).

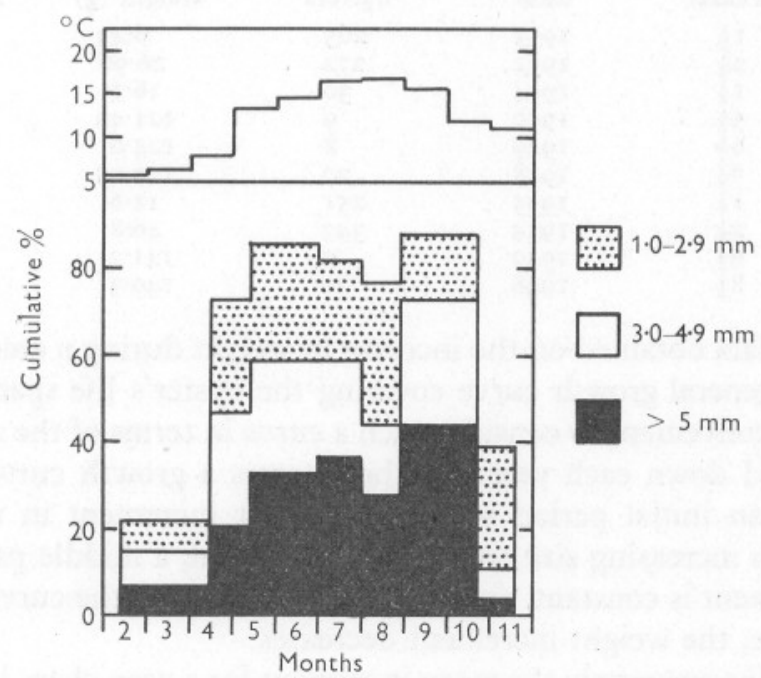

Fig. 8. The percentage of oysters showing shell shoots of varying size in different periods of 1953. The shell shoot has been taken as the maximum increase in either breadth or length.

Growth was retarded for 13 days but stopped only for 4 days. As both the Blackwater and the Fal produce large fat oysters, it is difficult to believe that food is inadequate for simultaneous growth and spawning. Orton, examining at weekly intervals, samples of oysters for the presence or absence of a shoot of new shell growth, decided that few had any shoot in the summer months and concluded that they were not growing. In my experience, the new shoot at 
the beginning of the year is readily seen, because, during the winter months, the shell becomes uniformly coloured, and the edge abraded, so that when growth starts the new clean white or transparent shell is very readily visible. In the summer, however, two factors disguise the new shoot: the more rapid growth of shell causes the new shoot to harden much more quickly so that less new flexible shell is seen, and, secondly, the increased growth of encrusting organisms, bacterial, algal and animal, colours the shell uniformly. I suggest that if Orton had studied the same oysters throughout the year, considerable growth would have been found during the summer months. The oysters kept as breeding stock in the Conway tanks during the summer months produce a considerable shell shoot despite a high rate of spawning.

\section{TABLE 1. ANNUAL INCREASE IN WEIGHT IN DIFFERENT YEARS OF CONWAY OYSTERS OF DIFFERENT AGES}

The oysters were kept in trays at low water mark of spring tides at Tal-y-foel.

\begin{tabular}{|c|c|c|c|c|c|}
\hline $\begin{array}{c}\text { Year of } \\
\text { observation }\end{array}$ & $\begin{array}{c}\text { Age at } \\
\text { beginning } \\
\text { of growing } \\
\text { season } \\
\text { (Years) }\end{array}$ & $\begin{array}{l}\text { Year } \\
\text { class }\end{array}$ & $\begin{array}{l}\text { No. of } \\
\text { oysters }\end{array}$ & $\begin{array}{c}\text { Initial mean } \\
\text { weight }(\mathrm{g})\end{array}$ & Increment (g) \\
\hline I955 & $I_{2}^{\frac{1}{2}}$ & I953 & 265 & 6.43 & $17 \cdot 19$ \\
\hline 1955 & $2 \frac{1}{2}$ & 1952 & 272 & $26 \cdot 96$ & $17 \cdot 24$ \\
\hline 1956 & I $\frac{1}{2}$ & 1954 & 30 & $16 \cdot 7$ & $25 \cdot 3$ \\
\hline 1956 & $5^{\frac{1}{2}}$ & 1950 & 9 & $\mathrm{I} 2 \mathrm{I} \cdot 42$ & 19.80 \\
\hline I956 & $6 \frac{1}{2}$ & 1949 & 8 & 124.0 & 8.0 \\
\hline I956 & $7 \frac{1}{2}$ & I948 & 20 & 129.05 & 13.65 \\
\hline I957 & I $\frac{1}{2}$ & I955 & $25 \mathrm{I}$ & 12.6 & $25 \cdot 50$ \\
\hline I957 & $2 \frac{1}{2}$ & I954 & 342 & $46 \cdot 8$ & $22 \cdot 92$ \\
\hline 1957 & $6 \frac{1}{2}$ & 1950 & 9 & $\mathrm{I} 4 \mathrm{I} \cdot 2$ & 23.5 \\
\hline I957 & $8 \frac{1}{2}$ & I948 & 20 & 140.3 & $20 \cdot 3$ \\
\hline
\end{tabular}

From the data obtained on the increase in weight during a season's growth (Table I), a general growth curve covering the oyster's life span can be suggested. It is convenient to consider such a curve in terms of the actual weight increment laid down each year. In these terms a growth curve is made of three parts: an initial period when the weight increment in a given time increases with increasing size and age of the animal, a middle part where the weight increment is constant, and a third part where, as the curve approaches the asymptote, the weight increment decreases.

To determine accurately the mean increment for a year-class, it is necessary to work with very large samples since any year-class is made up of fast, average and slow growing oysters, a point demonstrated by some data obtained in 1957. At the beginning of the growing season random samples of two year classes, I955 and I954, of Conway oysters were collected and the oysters, after being assigned to $4 \mathrm{~g}$ weight-groups, were planted in separate tray compartments. At the end of the growing season the mean weight increment per oyster was obtained for each group. Fig. 9, plotted from this data, shows that the larger oysters of a year class have bigger increments than the smaller ones. 
Since the oysters were of the same age, differences in initial size must have resulted from more rapid growth which was clearly continued into the experimental period. After several years growth these differences result in a considerable range of weights among any I-year-group. For example, at the end of 1957, a sample of twenty $8 \frac{1}{2}$-year-old oysters, which had been kept continuously in a cage, had individual weights varying from 9I to $235 \mathrm{~g}$.

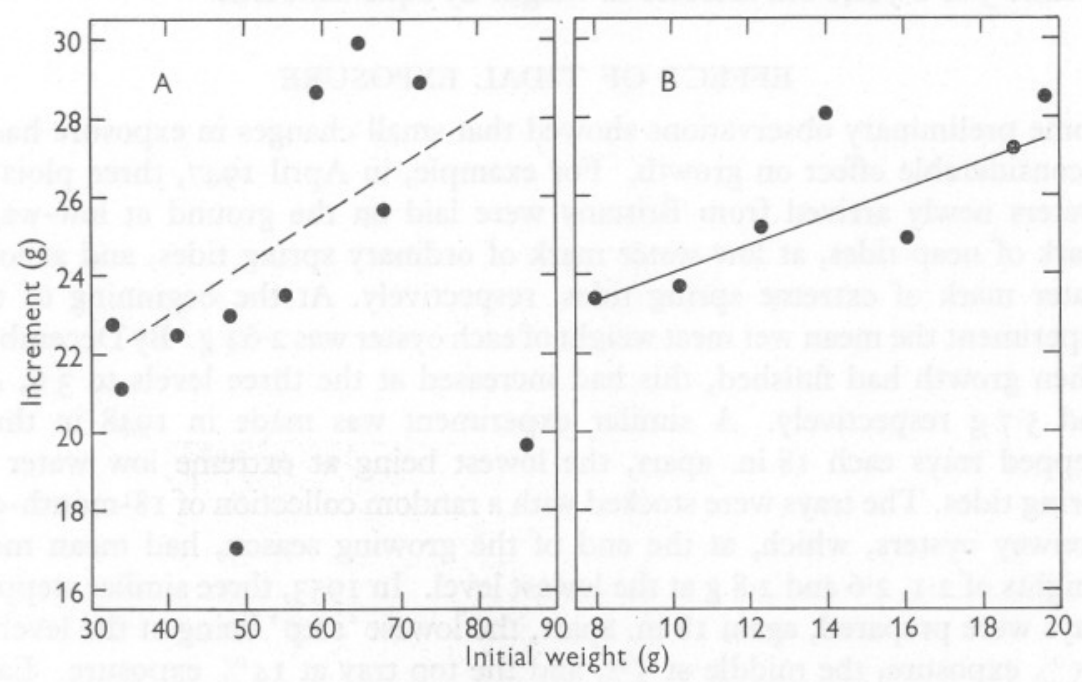

Fig. 9. The weight increment in samples of oysters of different initial weight but the same age during the 1957 growing season. (A) Oysters $3 \frac{1}{2}$ years old at the beginning of the growing season. Trend line fitted by eye. (B) Oysters $2 \frac{1}{2}$ years old at the beginning of the growing season. The line drawn is the regression giving the best estimate of the increment.

If these differences in growth rate are due, at least in part, to genetic factors, they provide a basis for selective breeding work. The existence of such differences does, however, show that a reliable average growth rate can only be obtained from very large samples.

During the first growing season after settlement, the spat, which weighed around $\mathrm{I}-2 \mathrm{~g}$ at the beginning, increased in mean weight by $5^{-} \mathrm{I} 5 \mathrm{~g}$, according to the year, so that at the end of this season (when $I \frac{1}{2}$ years old) the mean weight varied from 6 to $16 \mathrm{~g}$. In 1955 and 1957 there was an approximately equal weight increment in each year among oysters in their second and third growing seasons. The increment was larger than that occurring in younger oysters. This conclusion was confirmed (see below) during a study of growth at different levels on the shore. It is clear, therefore, that the change from an increasing size of weight increment with age to a constant increment irrespective of age occurs at about $\mathrm{I} \frac{1}{2}$ year old-at the end of the growing season following that in which settlement occurs. 
The age at which the size of the increment begins to decline has not been determined because of the scarcity of older oysters of known age. The data for 1956 suggested that a decrease might have started in oysters of $5 \frac{1}{2}-7 \frac{1}{2}$ years old, but this was contradicted by the 1957 data when oysters of $6 \frac{1}{2}$ and $8 \frac{1}{2}$ years old increased by approximately the same amount as those $\mathrm{I} \frac{1}{2}$ and $2 \frac{1}{2}$ years old. It may be reasonable to assume that in any I year oysters from $\mathrm{I} \frac{1}{2}$ years old to at least 5 or 6 years old increase in weight by equal amounts.

\section{EFFECT OF TIDAL EXPOSURE}

Some preliminary observations showed that small changes in exposure had a a considerable effect on growth. For example, in April 1947, three plots of oysters newly arrived from Brittany were laid on the ground at low-water mark of neap tides, at low-water mark of ordinary spring tides, and at lowwater mark of extreme spring tides, respectively. At the beginning of the experiment the mean wet meat weight of each oyster was $2.62 \mathrm{~g}$. By December, when growth had finished, this had increased at the three levels to $3 \cdot 6,4 \cdot 0$ and $5.7 \mathrm{~g}$ respectively. A similar experiment was made in 1948 in three stepped trays each 18 in. apart, the lowest being at extreme low water of spring tides. The trays were stocked with a random collection of I8-month-old Conway oysters, which, at the end of the growing season, had mean meat weights of $2 . \mathrm{I}, 2.6$ and $2.8 \mathrm{~g}$ at the lowest level. In I953, three similar stepped trays were prepared, again I 8 in. apart, the lowest 'step' being at the level of I. $5 \%$ exposure, the middle at $5 \%$ and the top tray at $14 \%$ exposure. Each tray was stocked with fifteen individually marked Conway oysters, half of them being 2-year-old and the rest 3-year-old; their mean diameters were recorded at intervals. The results, shown in the table below, show little difference between the $1 \cdot 5 \%$ and the $5 \%$ exposure level, but at the $14 \%$ exposure level growth was much reduced:

\begin{tabular}{|c|c|c|c|c|c|c|}
\hline \multirow[b]{2}{*}{ Exposure } & \multicolumn{3}{|c|}{ I949 year-group } & \multicolumn{3}{|c|}{ I950 year-group } \\
\hline & $\mathrm{I} \cdot 5 \%$ & $5 \%$ & $14 \%$ & $1 \cdot 5 \%$ & $5 \%$ & $\mathrm{I} 4 \%$ \\
\hline Diameter-March (mm) & 70 & 67 & 66 & 62 & 63 & 67 \\
\hline Diameter-November (mm) & 83 & 78 & 73 & $8 \mathrm{I}$ & 83 & 74 \\
\hline Increase (mm) & 13 & II & 7 & 19 & 20 & 7 \\
\hline
\end{tabular}

The data, when plotted, suggest that growth would have stopped at about $25-30 \%$ exposure. The amounts of growth made during different parts of the season varied similarly at all levels.

In 1955 a more detailed investigation was made. Six identical trays were erected individually $\mathrm{I} \mathrm{ft}$. above the level of the mud at positions on the shore ranging from I to $23 \%$ exposure. A further two trays were erected on much longer posts in order to compare the growth of oysters at the same tidal level but at different distances above the mud. Each tray was stocked with 100 I-year-old and Ioo 2-year-old Conway oysters; the two age-groups were 
kept separate. The diameters and weights of all oysters were recorded in April and October.

The results showed (Fig. Io) that growth was sensitively related to the percentage exposure to the air. Although the point of no growth was not quite reached, extrapolation suggests that it lay at the tidal level of about

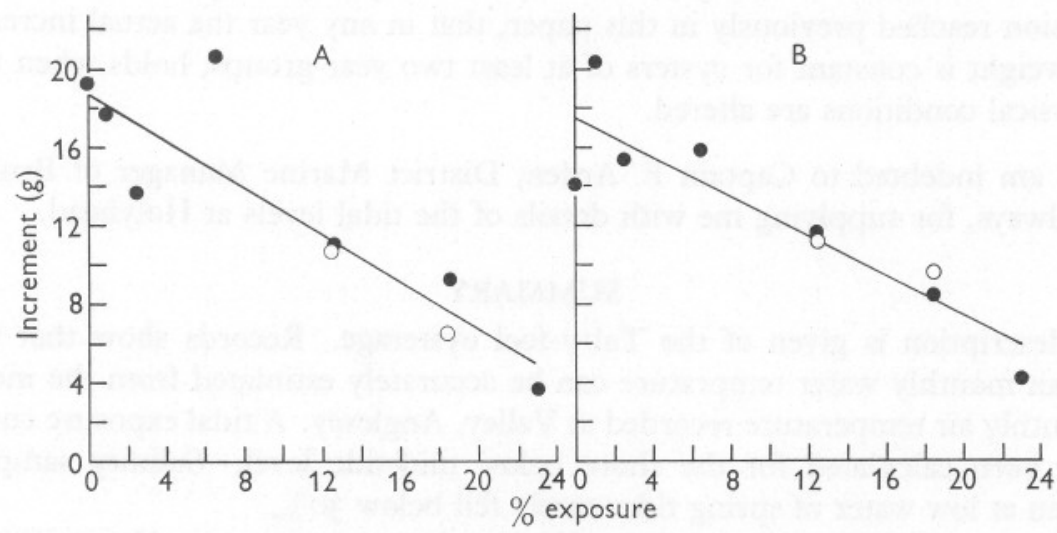

Fig. I0. The weight increment in 1955 of samples of roo oysters exposed at different levels on the shore. Solid circles-trays standing about I8 in. above the mud. Open circles-trays standing about $4 \mathrm{ft}$. above the mud. (A) $2 \frac{1}{2}$-year-old oysters. (B) $1 \frac{1}{2}$-year-old oysters.

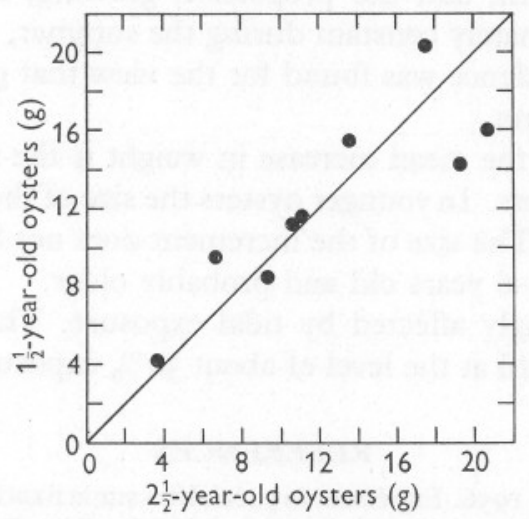

Fig. II. A comparison of the weight increase of oysters of two age-groups, both exposed at different levels on the shore. The line drawn is that of equal increment for each age-group.

$30 \%$ exposure, which agrees with the estimate from the 1953 experiment. If it is a simple relationship between growth and exposure, the data suggests that about three-quarters of the feeding activity is devoted to basal metabolism and the elaboration of reproductive products, while about one quarter is devoted to growth. 
The ratio of the shell weight to the meat weight was found to be approximately the same in samples examined from the different trays. During the experimental period of 6 months no observable systematic tendency towards the development of relatively heavier shells was discernable at any level.

It is noteworthy that at each level the mean increase in weight was the same for both the 2- and 3-year-old oysters (Fig. II). Apparently the conclusion reached previously in this paper, that in any year the actual increase in weight is constant for oysters of at least two year-groups, holds when the physical conditions are altered.

I am indebted to Captain F. Arden, District Marine Manager of British Railways, for supplying me with details of the tidal levels at Holyhead.

\section{SUMMARY}

A description is given of the Tal-y-foel oysterage. Records show that the mean monthly water temprature can be accurately estimated from the mean monthly air temperature recorded at Valley, Anglesey. A tidal exposure curve has been calculated for the shore below mid-tide level. Salinity samples taken at low water of spring tides rarely fell below $30 \%$.

The growth of oysters, determined by length measurements and by weighing, was confined to the period April to October inclusive, that is when the water temperature was above $10-12^{\circ} \mathrm{C}$.

The rate of growth, and the proportion growing, increased during the spring, was approximately constant during the summer, and declined during the autumn. No evidence was found for the view that growth is confined to the spring and autumn.

In any given year the mean increase in weight is the same for $1 \frac{1}{2}$-year-old and $2 \frac{1}{2}$-year-old oysters. In younger oysters the size of the increment increases with increasing age. The size of the increment does not begin to decline until oysters are at least 5-6 years old and probably older.

Growth was strongly affected by tidal exposure. The amount of growth decreases steadily until at the level of about $30 \%$ exposure no growth occurs.

\section{REFERENCES}

ANDREU, B. \& ARTÉ, P., I956. Expériences préalables sur la fixation des larves et la croissance hivernale des jeunes huitres (O. edulis) des Rias Galiciennes. Rapp. Cons. Explor. Mer, Vol. 140, Pt. 3, pp. 17-22.

Cole, H. A., I938. A system of oyster culture. F. Cons. int. Explor. Mer, Vol. I3, pp. $22 \mathrm{I}-35$.

Havinga, B., I928. The daily rate of growth of oysters during the summer. F. Cons. int. Explor. Mer, Vol. 3, pp. 23I-45.

KorRINGA, P., I955. Recent advances in oyster biology. Quart. Rev. Biol., Vol. 27, pp. 266-308.

OrTON, J. H. 1938. On rhythmic periods in shell-growth in Ostrea edulis, with a note on fattening. F. mar. biol. Ass. U.K., Vol. 15, pp. 365-427. 